Edutech, Tahun 13, Vol.1, No.1, Februari 2014

\title{
OPTIMALISASI FUNGSI HUMAS PEMERINTAH THE OPTIMIZATION OF GOVERNMENT PUBLIC RELATIONS FUNCTION
}

\author{
Oleh : Anwar Sani
}

Email : anwar.sani@unpad.ac.id

Universitas Padjadjaran

\begin{abstract}
, world democratization forces many organizations including the government in this case, of all types in many regions of the world, to consider giving more attention to the government public relations activities. The role will include contributing to good governance and respect for human rights. That would mean public relations in Indonesia, as elsewhere in Asia, will be involved in the development of public diplomacy. Aware of the problems as well as the demands of optimization and revitalization of the role of public relations in the era of reform, democratization and transparency of public information, Indonesian Ministry of Home Affairs issued the Regulation of the Minister of the Home Affairs (Permendagri) No. 13 of 2011, in which it sets the Implementation Guidelines for PR Tasks in the milieu of Ministry of Home Affairs and Local Government. The regulation represents the desire of the Ministry of Home Affairs to fix the government's role and functions of public relations in its internal milieu. The research question of this study concerns how the understanding of the public relations officer in the Ministry of Home Affairs of the Permendagri 13/2011 and how the implementation of Permendagri 13/2011 by public relations officials of Ministry of Home Affairs. The method used was qualitative method using the theory of social constructs of reality and symbolic interaction. The results showed that public relations officials in the Ministry of Home Affairs understood that the regulation was to improve the professionalism of Public Relations of the Ministry of Internal Affairs and as an effort to encourage the active participation of the public. While the background history of the regulation discovered in the implementation, there were efforts to socialize the regulation; its impacts, constraints and solutions related to its implementation and other four main public relations activities of the Ministry of Home Affairs which include public information services, public affairs, content analysis of media and crisis management.
\end{abstract}

Key words : government public relations, Regulation of the Minister of the Home Affairs $13 / 2011$

Abstrak, demokratisasi dunia memaksa organisasi, termasuk juga pemerintah dalam hal ini, dari semua jenis di banyak wilayah di dunia untuk mempertimbangkan memberikan perhatian lebih pada aktivitas kehumasan pemerintah. Peran yang akan mencakup kontribusi bagi pemerintahan yang baik dan menghormati hak asasi manusia. Itu akan berarti hubungan masyarakat di Indonesia, seperti di tempat lain di Asia, akan terlibat dalam upaya pengembangan diplomasi publik.

Sadar akan persoalan sekaligus tuntutan optimalisasi serta revitalisasi peran humas pemerintah di era reformasi, demokratisasi dan transparansi informasi publik, Kementerian Dalam Negeri Indonesia (Kemendagri) mengeluarkan Peraturan Menteri Dalam Negeri (Permendagri) Nomor 13 tahun 2011, yang di dalamnya mengatur Pedoman Pelaksanaan Tugas Kehumasan di Lingkungan Kementerian Dalam Negeri dan Pemerintah Daerah. Permendagri 13/2011 merepresentasikan keinginan Kementerian Dalam Negeri (Kemendagri) untuk membenahi peran serta fungsi Humas pemerintah di lingkungannya. 
Pertanyaan penelitian ini adalah bagaimana pemahaman para pejabat kehumasan di lingkungan Kemendagri terhadap Permendagri No.13 Tahun 2011 dan bagaimana implementasi Permendagri No.13 Tahun 2011 oleh pejabat kehumasan Kemendagri.

Metode penelitian yang digunakan adalah metode kualitatif dengan menggunakan teori kostruksi sosial atas realitas dan interaksi simbolik.

Hasil penelitian menunjukkan bahwa pejabat humas Kemendagri memahami Permendagri 13/2011 sebagai regulasi yang mendorong Humas Kemendagri untuk meningkatkan profesionalismenya dan merupakan upaya untuk mendorong partisipasi aktif publik. Sementara dalam implementasi Permendagri 13/2011 ditemukan beberapa latar belakang lahirnya Permendagri 13/2011, terdapat upaya sosialisasi Permendagri 13/2011, dampak, kendala serta solusi terkait implementasi Permendagri 13/2011 dan 4 aktivitas kehumasan utama Kemendagri yaitu layanan public information, public affairs, analisis isi media dan manajemen krisis.

Kata Kunci : government public relations, humas pemerintahan, indonesia, permendagri $13 / 2011$

\section{A. PENDAHULUAN}

Demokratisasi dunia, terutama di paruh kedua abad ke-20, telah memaksa organisasi, termasuk juga pemerintah dalam hal ini, dari semua jenis di banyak wilayah di dunia untuk mempertimbangkan memberikan kepentingan yang lebih besar untuk PR, demikian tulis Sriramesh dan Vercic (2003 : xxvi). Dalam konteks yang lebih Indonesia, Public Relations Society of Indonesia (PRSI) dalam Freitag dan Stokes (2009 : 130) menegaskan bahwa pasca berakhirnya rezim Orde Baru, yang ditandai dengan berakhirnya Presiden Soeharto, PR pemerintah memainkan peran yang lebih penting. Peran yang akan strategis Humas pemerintah dalam mencakup kontribusi bagi jalannya pemerintahan baik di pusat pemerintahan yang baik dan menghormati hak asasi manusia. Itu akan berarti hubungan masyarakat di Indonesia, seperti di tempat lain di Asia, akan terlibat dalam upaya pengembangan diplomasi publik.

Sadar akan persoalan sekaligus tuntutan optimalisasi serta revitalisasi peran humas pemerintah di era reformasi, demokratisasi dan transparansi informasi publik, Kementerian Dalam Negeri Indonesia (Kemendagri) melakukan serangkaian kajian. Kajian ini melahirkan suatu kebijakan yang kelak akan menjadi dasar hukum bagi pembenahan Humas pemerintahan. Mencermati peran 
Edutech, Tahun 13, Vol.1, No.1, Februari 2014

maupun di daerah, penulis tertarik peran Humas dalam lingkungan terhadap keluarnya Peraturan Menteri Kemendagri sendiri.

Dalam Negeri (Permendagri) Nomor

Upaya transformasi Humas

13 tahun 2011 (13/2011), yang di Kemendagri masuk ke dalam koalisi dalamnya mengatur Pedoman dominan tidak mudah jika tanpa Pelaksanaan Tugas Kehumasan di dukungan dari pimpinan lembaga. Lingkungan Kementerian Dalam Berkaitan dengan hal tersebut, Negeri dan Pemerintah Daerah. Kapuspen Kemendagri menjelaskan Permendagri ini lahir dengan bahwa Menteri Dalam Negeri, Dr. pertimbangan beberapa diantaranya, Gamawan Fauzi, mendukung serta perlu menetapkan pedoman mendorong revitalisasi dan optimalisasi pelaksanaan tugas kehumasan dalam peran Humas di lingkungan rangka meningkatkan peranan, tugas, Kemendagri untuk menjadi bagian dari dan fungsi dibidang kehumasan dalam koalisi dominan.

pelaksanaan urusan wajib bidang

Selain itu profesional Humas komunikasi dan informatika di Kemendagri juga dituntut untuk lingkungan Kementerian Dalam Negeri memiliki kepekaan terhadap perubahan dan Pemerintah Daerah.

Humas Kemendagri melalui kemasyarakatan. Kemampuan program-program kehumasannya membaca tren yang terjadi masyarakat menjadi penting diantaranya merupakan prasyarat dalam membangun dinamisasi, mendinamisir menyelaraskan informasi kehumasan proses dan akselerasi maupun dengan dinamika perubahan yang sinkronisasi penyelenggaraan mungkin terjadi pada tatanan pemerintahan baik di pusat maupun di masyarakat secara umum.

daerah. Lahirnya Permendagri No. Upaya ke arah transformasi 13/2011 merupakan landasan hukum tersebut diawali dengan menata bagi Kemendagri untuk merevitalisasi manajemen hubungan masyarakat yang profesional. Dalam hal ini Humas 
Edutech, Tahun 13, Vol.1, No.1, Februari 2014

Kemendagri melakukan pembenahan antara lain memberikan 'posisi" baru bagi Kapuspen Kemendagri yang merepresentasikan fungsi Humas Kemendagri, dalam organigram mereka. Posisi Humas Kemendagri dalam hal ini menjadi lebih strategis dan masuk ke dalam koalisi dominan. Posisi Kapuspen Kemendagri yang awalnya seolah terisolir dari sumber informasi dan kebijakan (Menteri Dalam Negeri dan jajaran Dirjen Kemendagri) kini semakin strategis. Sekat informasi yang dulu dirasakan sebagai akibat posisi Humas Kemendagri yang tidak strategis dan menjadi subordinat pada banyak departemen. Dengan terbukanya akses ke episentrum informasi lembaga, Humas Kemendagri bukan lagi menjadi pihak yang paling akhir tahu tentang perkembangan dan kebijakan lembaga. Khas departemen PR yang sudah mengadopsi manajemen PR koalisi dominan adalah memiliki tingkat keterlibatan yang tinggi dan intensif dengan pusaran informasi dan kebijakan lembaga. Praktisi PR pada konsep koalisi dominan menjelma menjadi pihak yang pertama kali tahu tentang perkembangan dan kebijakan lembaga.

Lahirnya Permendagri 13/2011 adalah untuk membuat peran pelaku Humas Pemerintah di lingkungan Kemendagri lebih baik dan ideal. Sehingga jangan sampai peraturan yang dibuat sebagai pedoman ke arah perbaikan tidak dijalankan dengan optimal. Berdasarkan permasalahan tersebut penulis ingin meneliti mengenai pemahaman para pejabat kehumasan di lingkungan Kementerian Dalam Negeri Republik Indonesia dan implementasi fungsi kehumasan pemerintah di kementerian tersebut setelah dikeluarkannya Permendagri 13/2011. Tujuan penelitian ini untuk mengetahui pemahaman para pejabat kehumasan di lingkungan Kementerian Dalam Negeri Republik Indonesia terhadap Permendagri No.13 Tahun 2011 dan implementasi Permendagri No.13 Tahun 2011 oleh pejabat kehumasan Kementerian Dalam Negeri Republik Indonesia.

\section{Bahan dan Metode}


Edutech, Tahun 13, Vol.1, No.1, Februari 2014

Jenis penelitian ini adalah Penelitian ini menggunakan studi kasus kualitatif, Creswell (1998: 37) (case study). Studi kasus adalah mendefinisikan metode kualitatif penelitian yang dilakukan pada obyek sebagai: Qualitative research is an tertentu dalam konteks kehidupan nyata inquiry process of understanding based (real life), bersifat temporer dan on distinct methodological tradition of spesifik. Penelitian ini melibatkan inquiry that explore a social or human kontak langsung dengan obyek problem. The researcher builds a penelitian, bersifat detail dan complex, holistic picture, analyzes menyeluruh (holistic). Dalam studi words, report detailed views of kasus, peneliti merupakan instrument informants, and conducts the study in riset utama.

natural setting.

Realitas bersifat relatif, maksudnya adalah bagaimana sebuah fenomena atau peristiwa dinilai secara relevan oleh pelaku sosial itu sendiri. Penulis sebagai peneliti memberikan penilaian terhadap realitas dari pelaksanaan fungsi dan peran Humas Pemerintah yang masih terkendala dengan peraturan-peraturan pemerintah itu sendiri. Oleh karena itu penulis ingin menemukan lebih dalam latar belakang dikeluarkannya Permendagri 13/2011 dan bagaimana implementasinya oleh pelaku atau pejabat kehumasan di lingkungan Kementerian Dalam Negeri Republik Indonesia.

\section{B. HASIL DAN PEMBAHASAN}

1. Pemahaman Pejabat Humas Kemendagri terhadap Permendagri 13/2011

a. Permendagri 13/2011 dan Fungsi Humas Kemendagri

Pelaku kehumasan Kemendagri memahami Permendagri $\quad 13 / 2011$ sebagai regulasi yang mendorong pelaku humas di lingkungan Kemendagri pada khususnya dan humas pemerintah daerah untuk menjalan fungsi kehumasannya secara ideal. Pemahaman ini merupakan 
Edutech, Tahun 13, Vol.1, No.1, Februari 2014

pemahaman yang sangat positif bagi perkembangan humas pemerintahan secara umum. Warna humas pemerintahan dewasa ini memang dituntut untuk lebih mampu berperan lebih optimal bagi lembaganya.Angin demokratisasi yang berhembus pada era reformasi yang dimulai dengan berakhirnya rezim orde baru membawa Indonesia masa dimana pemerintah dituntut untuk lebih transparan dan mempertinggi tingkat partisipasi publik dalam pembangunan. Sebagai pengejawantahannya aspirasi publik yang di masa orde baru sering membentur pada sekatsekat kekuasan, perlahan dengan runtuhnya sekat yang membatasi publik dengan penguasa (pemerintah), harus lebih bisa difasilitasi oleh pemerintah. Pertanyaannya kemudian bagaimana cara pemerintah untuk menyerap aspirasi publik dalam era demokratis ini. Artinya dalam hal ini pemerintah harus memiliki medium aspiratif guna menyerap, mengolah dan menyampaikan aspirasi publik pada pembuat kebijakan.

Pemerintah untuk memenuhi harapan tersebut perlu membangun sistem komunikasi politik dengan masyarakat melalui medium-medium dan fungsi-fungsi komunikasi politik yang efektif. Di sinilah peran humas pemerintah menyeruak sebagai solusi untuk pemerintah.

Public Relations Society of Indonesia (PRSI) dalam Freitag dan Stokes menegaskan : 
Edutech, Tahun 13, Vol.1, No.1, Februari 2014

Pasca berakhirnya rezim Orde Baru, yang ditandai dengan berakhirnya Presiden Soeharto, PR pemerintah memainkan peran yang lebih penting. Peran yang akan mencakup kontribusi bagi pemerintahan yang baik dan menghormati hak asasi manusia. Itu akan berarti hubungan masyarakat di Indonesia, seperti di tempat lain di Asia, akan terlibat dalam upaya pengembangan diplomasi publik. (2009 : 130)

Menyangkut peran tersebut PRSI menekankan bahwa praktisi Humas pemerintah dibutuhan untuk melakukan komunikasi politik dalam rangka mengatasi isu-isu seperti kesejahteraan umum, perdamaian dan stabilitas. PRSI juga melihat tanggung jawab para praktisi Humas untuk membantu membangun reputasi Indonesia di mata dunia internasional, peka terhadap penggunaan teknologi komunikasi baru

$$
\begin{aligned}
& \text { dalam menimbulkan } \\
& \text { semangat warga negara } \\
& \text { untuk bekerja sama } \\
& \text { mencapai kestabilan pasca } \\
& \text { reformasi. } \\
& \text { Warna perubahan } \\
& \text { dalam Permendagri } \\
& \text { 13/2011 juga dipahami } \\
& \text { pelaku kehumasan } \\
& \text { kemendagri sebagai upaya } \\
& \text { revitalisasi fungsi Humas }
\end{aligned}
$$

Kemendagri. Posisi humas dari dianggap tidak penting bagi lembaga berubah menjadi posisi yang mememiliki peran strategis dalam sebuah lembaga. Untuk menjadi sebuah fungsi yang strategis dalam sebuah lembaga, Permendagri 13/2011 merevitalisasi peran pelaku kehumasan Kemendagri dengan membuka akses informasi langsung pada pimpinan.

Terkait akses informasi langsung pelaku kehumasan ke pimpinan 
Edutech, Tahun 13, Vol.1, No.1, Februari 2014

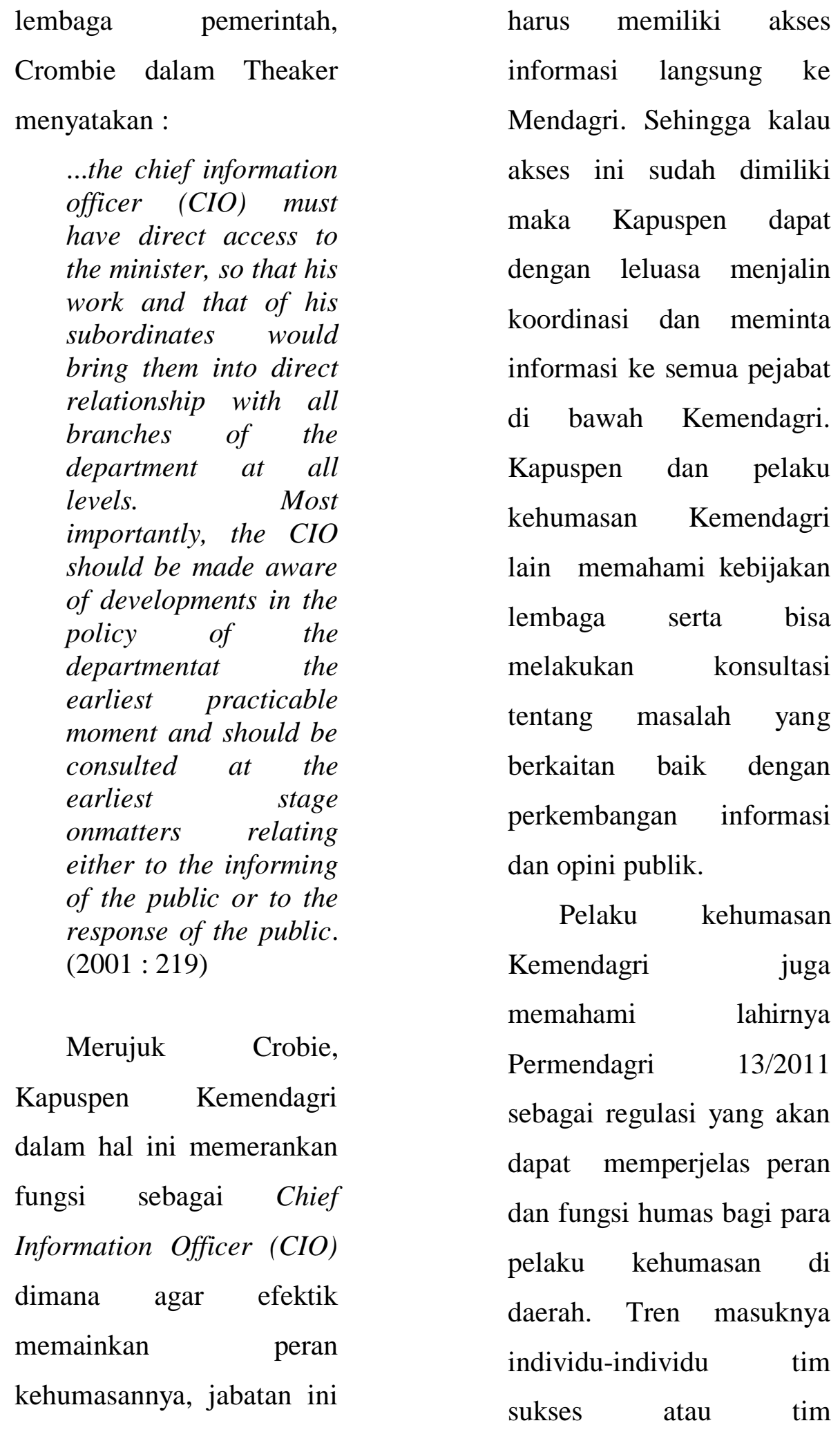


Edutech, Tahun 13, Vol.1, No.1, Februari 2014

pemenangan pemilu kepala

daerah tertentu ke dalam

inner circle kekuasaan turut

memberi andil atas

kemandulan fungsi dan

peran humas daerah. Alih-

alih menempati posisi

sebagai staf atau tenaga

ahli kepala daerah,

keberadaan tim sukses ini

malah memainkan peran

sebagai humas personal

kepala daerah.

Menjalankan aktivitas

aktivitas kehumasan demi

kepentingan pembangunan

citra personal kepala

daerah, bukan lembaga

apalagi daerah.

Permendagri $\quad 13 / 2011$

membatasi peran tim

sukses dengan memberikan

aturan pada kepala daerah

untuk mengoptimalkan

peran humas lembaga.

Sehingga dengan demikian

Permendagri 13/2011

secara tak langsung akan memperkuat posisi humas pemerintah di daerah.

b. Permendagri 13/2011 dan Gaya Hubungan Media Humas Kemendagri

Selain itu Permendagri 13/2011 juga dimaknai sebagai regulasi yang mengarahkan para pelaku kehumasan Kemendagri untuk berubah demi menyelaraskan diri dengan tuntutan perubahan jaman. Warna dan karakter Kemendagri yang pada masa orde baru cenderung kaku dan semi, kalau tidak mau disebut militeristik, melekat pada lembaga, cara dan teknik komunikasi publiknya. Regulasi ini menghendaki gaya humas Kemendagri lebih koorporatif, informatif dan peka terhadap kebutuhan publik.

Gaya kehumasan Kemendagri yang lebih kooperatif mengarah pada 
Edutech, Tahun 13, Vol.1, No.1, Februari 2014

penjelasan Tench dan

Yeoman bahwa sebuah

lembaga dianggap

kooperatif adalah tatkala

memenuhi aspek dimana

lembaga memiliki jaringan

untuk memaksimalkan

dukungan terhadap

kebijakan lembaga mereka.

Lembaga yang koorperatif

juga bergabung dengan

asosiasi untuk memperkuat

keberadaan (2006 : 449450).

Kedekatan media dengan Kemendagri tak bisa dilepaskan dari upaya pelaku kehumasan

Kemendagri menjalin

hubungan baik dengan media. Selain itu, Mendagri Gamawan Fawzi juga dikenal sebagai satu dari sedikit pejabat kenegaraan yang mempunyai kemampuan pendekatan dengan para wartawan. Kedekatan narasumber dengan wartawan memang memudahkan kerja jurnalisme wartawan. Wartawan cenderung menyukai lembaga yang tidak pelit informasi. Narasumber yang memiliki kedekatan, informasi yang komprehensif, akurat dan mudah diakses atau dihubungi sangat disukai wartawan.

Pelaku humas Kemendagri menjadikan hubungan media sebagai salah satu aktifitas utama kehumasan mereka. Hal tersebut dapat dimaklumi, mengingat media mempunyai kemampuan menyebarluaskan informasi secara serentak ke pelosok negeri. Selain itu kecenderungan pelaku kehumasan pemerintah menganggap humas itu adalah media relations, aktivitas kehumasan tertua bagi pelaku humas 
Edutech, Tahun 13, Vol.1, No.1, Februari 2014

pemerintah, tulis Tench dan

Yeomans (2006 : 589)

Hubungan dengan media yang baik akan dapat meningkatkan citra 'merek' Kemendagri dimata publik. Dalam konteks hubungan masyarakat modern memang cenderung tidak ada dikotomi bahwa merek adalah milik perusahaan swasta semata. Merek juga melekat pada sebuah lembaga pemerintahan. Keuntungan kedua adalah Kemendagri akan mendapat 'bonus' berupa tingginya angka peliputan dan perhatian media. Bukan cuma tingginya frekuensi dan kuantitas pemeberitaan, namun secara kualitatif juga memberikan nada positif bagi setiap pemberitaannya.

\section{c. Permendagri 13/2011 dan}

Humas Kemendagri : Koalisi Dominan

Permendagri $\quad 13 / 2011$ dimaknai sebagai regulasi yang mendorong dan mendukung pelaku kehumasan untuk percaya diri menjadi wajah lembaga. Artinya, pelaku kehumasan dengan kegiatankegiatannya harus mampu merepresentasikan Kemendagri. Hal ini bukanlah hal yang sederhana. Kepercayaan diri pelaku humas untuk mengemban tugas mewakili lembaga membutuhkan dukungan regulasi yang kuat. Peran humas sebagai wajah lembaga, menuntut pelaku humas untuk mampu menciptakan persepsi publik yang positif terhadap lembaga. Selain itu, peran merepresentasikan lembaga juga dibutuhkan untuk membangun interaksi lembaga dengan pihak-pihak yang terkait dengan Kemendagri. Peran sebagai wajah lembaga juga menjadikan pelaku kehumasan sebagai unit yang berperan menyebarluaskan informasi lembaga. Terakhir, dengan kemampuan merepresentasikan 
Edutech, Tahun 13, Vol.1, No.1, Februari 2014

lembaga, pelaku kehumasan

Kemendagri juga mampu membangun citra lembaga.

Syarat pertama agar pelaku humas dapat efektif dan optimal dalam menjalankan fungsinya adalah bagian ini harus dimasukkan ke dalam struktur organisasi utama dalam sebuah lembaga. Sehingga bagian ini mendapatkan akses informasi dan koordinasi langsung ke pemimpin lembaga. Kemudian Grunig mempopulerkan hal ini sebagai koalisi dominan. Syarat kedua, semua program-program komunikasi lembaga harus terintegrasi dan dikoordinasi oleh bagian humas sebuah lembaga, melalui kepala bagian kehumasan lembaga tersebut.Selanjutnya, masih menurut Grunig, syarat yang ketiga adalah bagian humas tidak boleh berada di bawah bagian lain. Syarat terakhir bagian humas harus terstruktur secara horizontal untuk mencerminkan posisi strategisnya, dan sehingga memungkinkan untuk menetapkan pelaku kehumasan yang baru untuk melanjutkan program-program lama serta menjalan program-program baru yang strategis.

Posisi Kapuspen sebagai ujung tombak fungsi kehumasan Kemendagri merupakan anggota koalisi dominan di Kemendagri. Kapuspen dan beberapa Kepala Bidang (Kabid) dibawahnya merupakan bagian yang menjalankan fungsi kehumasan Kemendagri. Dalam bagan tersebut mendapat akses suplai dan koordinasi informasi langsung dengan Mendagri, Sejen dan para Dirjen di lingkungan Kemendagri.

\section{d. Permendagri 13/2011 dan} Profesionalime Pejabat

\section{Humas Kemendagri}

Kepercayaan kepada pelaku kehumasan Kemendagri untuk masuk ke dalam area koalisi dominan Kemendagri 
Edutech, Tahun 13, Vol.1, No.1, Februari 2014

menuntut pelaku kehumasan

Kemendagri untuk memenuhi standar profesionalisme kehumasan. Terkait profesionalisme dalam Humas, Global Alliance of Public Relations Associations pada tahun 2000 mendeklarasikan beberapa prinsip dasar tentang profesionalime dalam humas. Berikut tulis Theaker mengutip deklarasi tersebut :

1. mastery of a particular intellectual skill through education and training

2. acceptance of duties to a broader society than merely one's clients or employers

3. objectivity

4. high standards of conduct and performance (2001 : 68)

Asosiasi PR yang menjadi mitra Public Relations Society of Indonesia (PRSI) itu menegaskan bahwa untuk menjadi pelaku humas yang profesional harus memiliki beberapa kriteria. Pertama menguasai beberapa standar kemampuan intelektual melalui pendidikan atau pelatihan di bidang kehumasan. Kedua semacam pengakuan terhadap eksistensinya dari lembaga maupun dari publik yang merasakan prestasi kerjanya. Ketiga obyektivitas dan terakhir, memiliki standar dalam kerja dan performanya.

\section{e. Permendagri 13/2011 dan Partisipasi Aktif Publik}

Persoalan mendorong partisipasi publik bukanlah hal yang sederhana. Euforia demokratisasi yang terjadi di Indonesia pasca 1998 membuat partisipasi publik murni kerap kali terkontaminasi dengan dengan kepentingankepentingan pihak tertentu yang mengatasnamakan kepentingan publik. Maka peran humas pemerintah dalam hal ini adalah menjalankan peran sebagai pelayan informasi publik sekaligus sebagai mitra publik untuk cerdas serta sehat dalam memanfaatkan informasi.

Peran ini tidak mudah, karena warna politik sebelum 
Edutech, Tahun 13, Vol.1, No.1, Februari 2014

era reformasi yang cukup tertutup terhadap hak informasi publik, membuat karakter banyak badan publik, termasuk juga Kemendagri terjebak dalam warna yang tidak terlalu ramah dengan akses informasi publik. Singkat kata, alih-alih menciptakan keterbukaan informasi publik, sebuah pemerintahan otoriter malah menawarkan komunikasi politik dengan nada propaganda yang berpihak pada status quo. Kecenderungan tersebut tercermin pada sebuah riset yang dilakukan The Phillis Report di Inggris seperti yang dipaparkan dalam Tench dan Yeoman (2006 : 91).

Maka dalam riset tersebut muncul beberapa rekomendasi tentang pelaksanaan komunikasi pemerintah pada publiknya.

Pertama, pemerintah harus melakukan redefinisi tentang peran dan cakupan komunikator pemerintah dengan mengembangkan gaya komunikasi dialogis dan dilakukan oleh pelaku-pelaku komunikasi yang profesional. Selanjutnya membangun struktur pusat komunikasi publik yang kuat, serta merekrut dan melatih tenaga profesional untuk menjadi komunikator pemerintah guna meningkatkan kualitas layanan informasi publik. (Tench dan Yeoman, 2006 : 91)

\begin{tabular}{lrr}
\multicolumn{1}{c}{ Sikap } & Kemendagri \\
meluncurkan & Permendagri \\
$13 / 2011$ & senada & dengan
\end{tabular}
rekomendasi The Phillis Report dalam rekomendasi penelitiannya. Seperti di bahas pada bagian sebelumnya, Permendagri 13/2011 merubah warna komunikasi politik Kemendagri terhadap publiknya. Pelaku humas Kemendagri menjalan fungsi komunikator politik Kemendagri dengan membangun program-program kehumasan yang diharapkan mampu meruntuhkan sekatsekat informasi komunikasi publik Kemendagri. Maka pelaku kehumasan Kemendagri menciptakan gaya komunikasi 
Edutech, Tahun 13, Vol.1, No.1, Februari 2014

dua arah dalam rangka fungsi sebagai pelayan menangkap aspirasi publik informasi publik dengan baik. sekaligus tetap menjalankan

f. Model Pemahaman Pejabat Humas Kemendagri terhadap Permendagri 13/2011

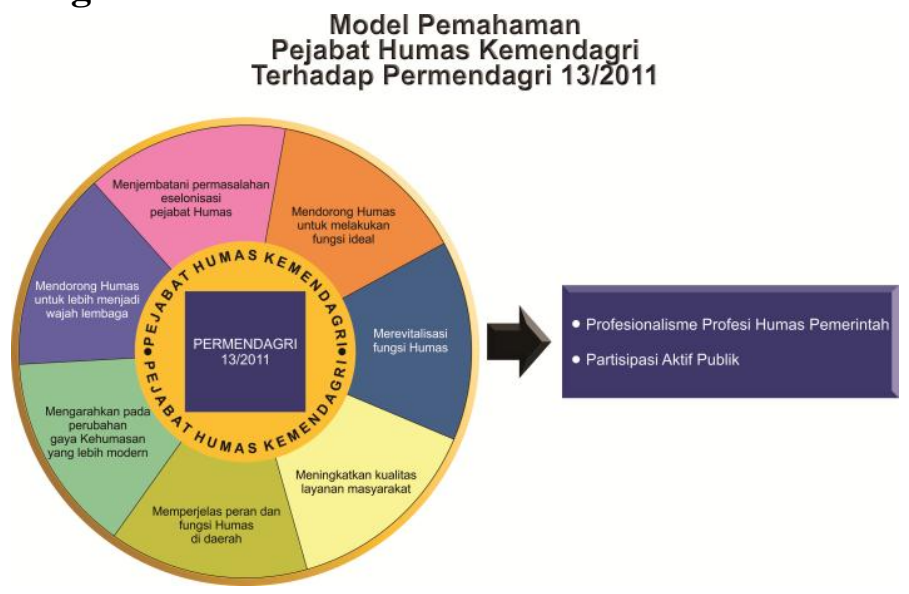

Model 2.1

Model Pemahaman Pejabat Humas Kemendagri Terhadap Permendagri 13/2011 (Sumber : Hansi Penelitian)

g. Latar Belakang Lahirnya

Permendagri 13/2011

Perubahan gaya humas pemerintahan yang modern menyangkut persoalan budaya. Maka pada dasarnya melalui Permendagri No. 13/2011 diharapkan kultur Humas Kemendagri mengalami transformasi budaya. Berubah dari pola dan kultur birokratif menjadi kultur korporatif. Kultur birokratif yang melekat pada peran, fungsi hingga kualitas SDM humas pemerintah yang cenderung kaku, tidak berani, tidak kreatif serta tidak peka terhadap perubahan dan tuntutan jaman, harus berubah menjadi Humas yang berkultur korporatif yang lebih mengedepankan semangat serta mentalitas kompetitif. Perubahan tersebut menurut Kapuspen, berdasarkan profesionalisme, kompetensi dan diferensiasi struktur. 
Edutech, Tahun 13, Vol.1, No.1, Februari 2014

Robert Leach membuat keterkaitan antara perkembangan demokrasi dan tuntutan peran Humas pemerintah yang ideal.

Democracy is now taken for granted over much of the modern world, although for nearly all states it is relatively recent, fragile and imperfect. The growth of public relations has been linked to the growth of democracy, as the need arose to communicate persuasively. (Tench dan Yeomans, 2006 :79)

Indonesia dalam konteks tersebut merupakan negara yang mengklaim sebagai negara demokratis, sehingga keterbukaan informasi dan komunikasi antara pemerintah dan warga negara menjadi sebuah ikon demokrasi yang tidak bisa dilepaskan. Kemendagri sebagai bagian dari bangsa Indonesia bahkan menjadi ujung tombak pemerintah untuk membangun komunikasi politik yang persuasif antara pemerintah dengan publik. Fungsi

komunikasi persuasif tersebut salah satunya melekat pada peran pelaku kehumasan Kemendagri. Leach menegaskan bahwa Humas (pemerintah) yang menjalankan fungsi dan peranannya secara ideal akan memberikan kontribusi positif dalam proses dinamika demokrasi.

\section{h. Sosialisasi Permendagri}

\section{$13 / 2011$}

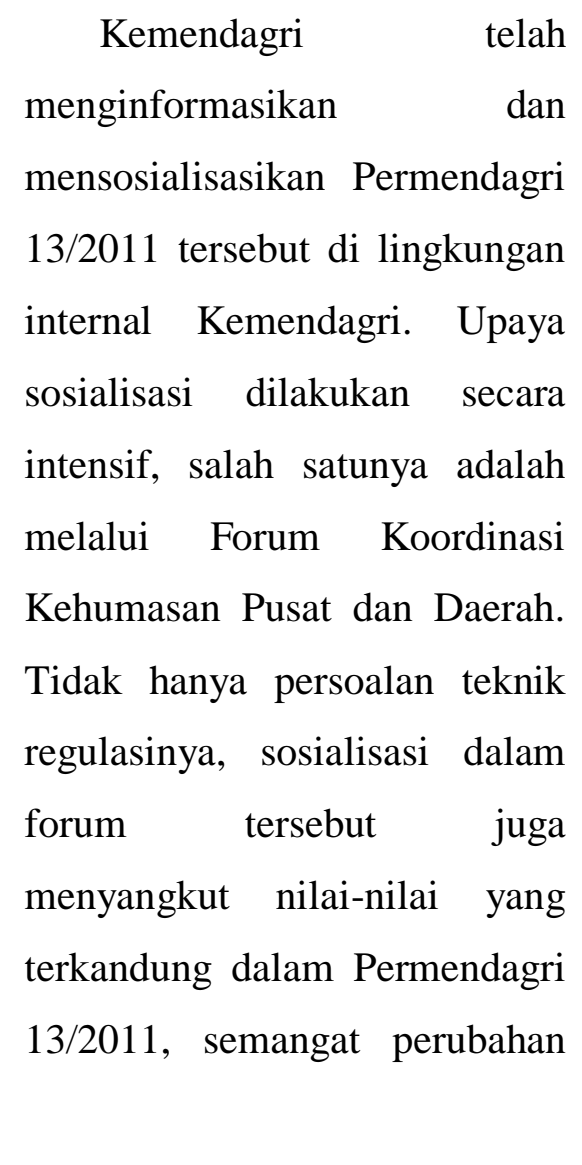


Edutech, Tahun 13, Vol.1, No.1, Februari 2014

dan penguatan peran dan fungsi

Humas di daerah.

Sosialisasi Permendagri

13/2011 juga dilakukan pada momen-momen pertemuan formal non formal. Baik pertemuan dengan para kepala daerah di pusat maupun di daerahnya masing-masing. Sebagai salah satu upaya sosialisasi Permendagri 13/2011 maka bekerjasama dengan Badan Diklat Kemendagri, telah disusun kurikulum pendidikan kehumasan di lingkungan Kemendagri dan Daerah. Kurikulum ini akan disampaikan dalam bentuk pendidikan dan pelatihan kehumasan. Adapun kurikulumnya sendiri dibagi menjadi 3 tingkatan. Tingkat satu bernuansa Dasar-dasar Manajemen diberikan kepada pejabat eselon 3 dan 4 . Tingkat dua nuansanya sudah semakin mengarah pada kurikulum kehumasan, yaitu Dasar Manajemen Kehumasan yang diberikan pada pejabat eselon 2 , 3 dan 4. Sementara, tingkat 3 kurikulum berisikan Orientasi Kehumasan yang diberikan pada level pengambil kebijakan dan keputusan untuk eselon 2 dan 1.

\section{i. Dampak}

Lahirnya

\section{Kemendagri 13/2011}

Setelah diterbitkan, diberlakukan dan sosialisasikannya Permendagri 13/2011, fungsi kehumasan di lingkungan Kemendagri diakui sudah sangat berjalan dengan baik. Hal ini terlihat dari komponen-komponen yang hendak melakukan tugasnya sudah mau berkonsultasi dengan dengan pelaku kehumasan Kemendagri. Fungsi komunikasi komponenkomponen ini, khususnya yang ditujukan ke publik eksternal seperti media dan masyarakat, dijalankan oleh Pusat Penerangan Kemendagri.

Koordinasi pelaku kehumasan Kemendagri dengan 
Edutech, Tahun 13, Vol.1, No.1, Februari 2014

komponen-komponen lain

dalam Kemendagri dalam

mengumpulkan, mengelola dan

menyebarluaskan informasi

kepada publik adalah bentuk integrated communication.

Bentuk ini penting untuk menjada konsistensi dan keakuaran informasi sebelum dan setelah disampaikan kepada publik. "Integrated communications strategy is essential, with consistent messages being communicated to diverse audiences", demikian tulis Tench dan Yeoman (2006: 444).

j. Kendala dalam Implementasi Permendagri 13/2011

Kendala pertama yang dihadapi Kemendagri dalam penerapan Permendagri 13/2011 antara lain adalah masalah kurang sinerginya beberapa regulasi yang mengatur aktifitas kehumasan pemerintah khususnya di daerah. Adanya beberapa peraturan yang tidak sinkron dengan dengan Permendagri $13 / 2011$, antara lain peraturan Kemkominfo dan peraturan Kemenpan tentang kehumas yang masih belum sinkron dengan Permendagri 13/2011.

Merujuk pada tanggal ditetapkannya, Permendagri 13/2011 lahir paling terakhir jika dibandingkan dengan 2 kementerian yang lain. Permendagri 13/2011 pun lahir jauh hari setelah batas akhir yang ditetapkan dalam SKB 3 Menteri, yaitu 30 Agustus 2007. Sementara Permenkominfo 10/2010 tentang PPID dilahirkan 8 bulan lebih cepat dari Permendagri 13/2011. Jadi, dalam konteks momentum adopsi regulasi, di pemerintah daerah pada khususnya, Permenkominfo 10/2010 lebih dahulu dari pada Permendagri $13 / 2011$.

\section{k. Solusi Terhadap Kendala dalam Implementasi} Permendagri 13/2011 
Edutech, Tahun 13, Vol.1, No.1, Februari 2014

Guna menyikapi masalah peningkatan pemahaman dan kemampuan aktivitas kehumasan misalnya, Kemendagri secara rutin menggelar seminar dan diskusi kehumasan. Selain mengikuti seminar dan diskusi, pelaku humas pemerintah daerah juga bisa mengagendakan workshop atau bimbingan teknis dengan mengundang pelaku kehumasan Kemendagri. Kemendagri terus berupaya melakukan penambahan tenaga fungsional di bidang kehumasan yang biasa disebut sebagai Pranata Humas.

Peningkatan pemahaman dan kemampuan pelaku kehumasan pemerintah secara umum memang menjadi kendala yang cukup pelik dalam upaya merevitalisasi fungsifungsi dan peran humas pemerintah. Pada banyak kesempatan, penulis menyoroti masalah rekrutmen dan penempatan pegawai untuk menjadi pelaku kehumasan yang kurang memadai. Banyak pelaku kehumasan pemerintah yang tidak tidak memiliki latar belakang pendidikan kehumasan. Memang belakangan ditemukan sebuah kecenderungan semakin seringnya lowongan penerimaan pegawai negeri yang membutuhkan pelaku kehumasan dan mencantumkan pendidikan kehumasan atau komunikasi sebagai salah satu syaratnya kualifikasinya. Namun jumlahnya rekrutmen pelaku kehumasan pemerintah dengan latar belakang pendidikan humas dan komunikasi, masih belum sebanding dengan jumlah pelaku kehumasan pemerintah yang tidak berlatar belakang pendidikan humas atau komunikasi.

\section{1) Aktifitas Kehumasan Utama Kemendagri : Layanan Informasi Publik}


Edutech, Tahun 13, Vol.1, No.1, Februari 2014

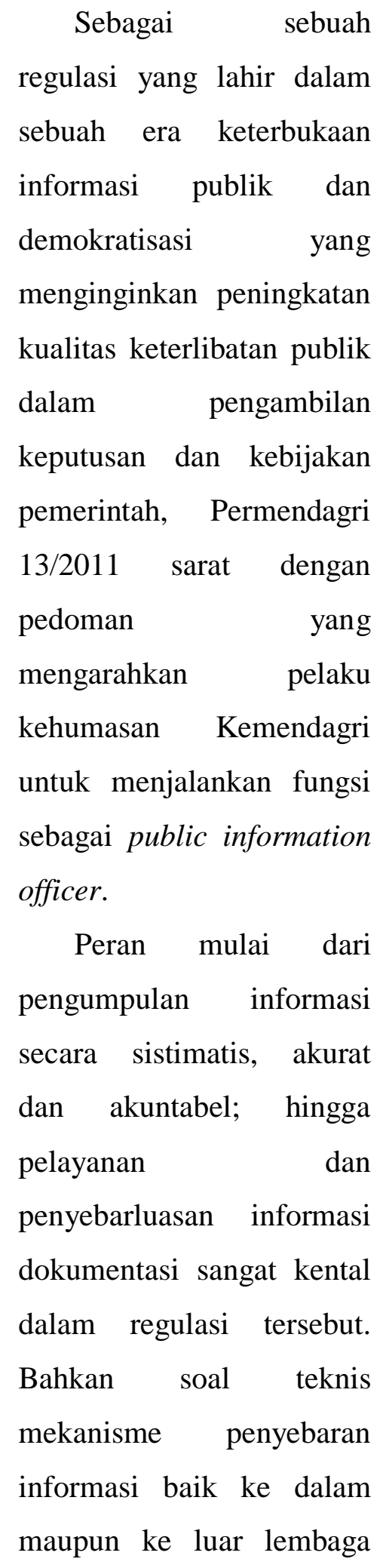

diatur dalam bab tersendiri.

Hal ini wajar mengingat Kemendagri adalah salah satu kementerian utama yang potensi sumber informasinya sangat besar dan berkongruensi dengan banyak tema kebutuhan informasi publik.

Fungsi informasi publik memang menjadi karakter dari pelaku humas pemerintah. Harrison dalam Tench dan Yeoman, berpendapat bahwa, "government traditionally operated at the 'public information . . . end of public relations". (2006 : 590). Terkait Harrison, Theaker menambahkan :

Local and central government continue to practise public information communication. Press releases giving details of committee decisions, budget allocation, or movement of personnel are typical public information activities. In recent years, the 
Edutech, Tahun 13, Vol.1, No.1, Februari 2014

shift from public to private sector utilities has placed a similar emphasis on the need to explain pricing policies to customers. Many large organisations have improved their 'transparency' - the availability of information to the public. Much of this has been improved or driven - by improved technology via the internet. (2001: 13)

Harrison beranggapan bahwa fungsi public information adalah ciri khas humas pemerintahan di manapun. Keberadaan pemerintah sebagai pengelola urusan publik berimplikasi pada posisi pemerintah sebagai pelayan kebutuhan publik. Dalam ranah kebutuhan informasi publik lah area peran pelaku kehumasan dilakukan.

Theaker memperjelas Harrison. Baginya pemerintah pusat dan daerah harus terus meningkatkan kualitas layanan informasi publiknya. Informasi yang disampaikan pada publik harus memberikan rincian informasi secara sistimatis, akurat dan akuntabel. Menurut Theaker, dalam beberapa tahun terakhir, terjadi pergeseran dari publik dan berakibat banyak lembaga telah meningkatkan tingkat transparansi mereka. Transparansi itu sendiri ditandai dengan kemudahan dan ketersediaan informasi kepada publik. Apalagi dalam era keterbukaan informasi juga diwarnai dengan ledakan teknologi informasi yang membuat kualitas dan kuantitas informasi publik semakin kuat dan terbuka. 
Edutech, Tahun 13, Vol.1, No.1, Februari 2014

2) Aktifitas Kehumasan

Utama Kemendagri :

\section{Public Affair}

Sekilas aktivitas public affair, adalah spesialisasi kehumasan dalam wilayah praktik kehumasan swasta. Namun ternyata tidak, badan publik, seperti lembaga pemerintah pun juga penting untuk melakukan spesialisasi kehumasan ini.

UU $14 / 2008$

mendefinisikan Badan

Publik sebagai :

Badan Publik adalah lembaga eksekutif, legislatif, yudikatif, dan badan lain yang fungsi dan tugas pokoknya berkaitan dengan penyelenggaraan negara, yang sebagian atau seluruh dananya bersumber dari anggaran pendapatan dan belanja negara dan/ atau anggaran pendapatan dan belanja daerah, atau organisasi nonpemerintah sepanjang sebagian atau seluruh dananya bersumber dari anggaran pendapatan dan belanja negara dan/ atau anggaran pendapatan dan belanja daerah, sumbangan masyarakat , dan/ atau luar negeri. (UU 14/2008, Pasal 1, poin 3 )

Kemendagri

dengan fungsi eksekutif,

menurut UU tersebut

adalah salah satu contoh

Badan Publik wajib

menyediakan, memberikan

dan/ atau menerbitkan

Informasi Publik yang

berada dibawah

kewenangannya kepada

Pemohon Informasi Publik,

selain informasi yang

dikecualikan sesuai dengan

ketentuan. Maka sudah

barang tentu warna

pelayanan publik menjadi

karakter yang menonjol

pada aktivitas kehumasan

para pelaku humasnya.

Tench dan Yeoman memberi penjelasan bahwa, "Public affairs (PA) is a crucial and demanding specialism inside the 
Edutech, Tahun 13, Vol.1, No.1, Februari 2014

broader field of public relations. Public affairs is not confined to commercial organisations; public sector bodies and charities need public affairs as well." (2006 : 448). Istilah Tench dan Yeoman "public sector bodies" merefleksikan kepada sebuah lembaga yang disebut sebagai Badan Publik oleh UU 14/2008.

Tench dan Yeoman sendiri mendefinisikan public affairs sendiri sebagai "a public relations specialism that seeks to influence public policy making via lobbying and/or through the media." (2006 :449) Terkait dengan definisi tersebut aktifitas public affair yang dilakukan oleh para pelaku kehumasan Kemendagri antara lain adalah melakukan pendekatanpendekatan yang intensif dan harmonis kepada publik guna membangun pemahaman publik terhadap kebijakan, regulasi hingga programprogram kementerian.

3) Aktifitas Kehumasan Utama Kemendagri : Analisis Isi Media

Pelaku kehumasan Kemendagri dalam kesehariannya melakukan tugas analisis berita dan media. Tujuan dari analisa media adalah menangkap bagaimana tone pemberitaan tentang Kemendagri. Kegiatan ini dilakukan setiap hari dengan melakukan analisa isi berita.

Agar hasil analisa itu obyektif, maka humas Kemendagri melibatkan tenaga profesional yang independen dan kompeten. Obyektifitas dalam menganalisa berita sangat penting bagi pelaku 
Edutech, Tahun 13, Vol.1, No.1, Februari 2014

kehumasan Kemendagri, agar masukan informasi yang ditangkap oleh lembaga bisa bersifat netral dan secara obyektif pula bisa disikapi oleh pembuat kebijakan. Pelaku kehumasan Kemendagri melakukan pemetaan dan identifikasi media. Hal ini penting untuk mengetahui ke mana arah afiliasi sebuah media dan bagaimana dinamika berita tersebut. Dengan demikian pelaku kehumasan Kemendagri mampu mengenali karakter media dan karakter pemberitaan media yang meliput aktifitas Kementerian.

$\begin{array}{lr}\text { Sebagai r } & \text { sebuah } \\ \text { lembaga } & \text { pemerintah } \\ \text { dengan output kebijakan } \\ \text { yang ramah dan memenuhi } \\ \text { kebutuhan dan kepentingan } \\ \text { publik, maka pelaku } \\ \text { kehumasan Kemendagri } \\ \text { perlu melakukan media }\end{array}$

monitoring, guna memantau bagaimana perkembangan dan dinamika aspirasi publik. Selain itu media monitoring juga dilakukan dalam rangka menatap bagaimana sikap publik terhadap kebijakan atau program yang dilakukan Kemendagri. Lebih jauh lagi dengan media monitoring, pelaku kehumasan Kemendagri bisa menangkap bagaimana citra dan reputasi Kemendagri di mata publik.

4) Aktifitas Kehumasan Utama Kemendagri : Manajemen Krisis

Sebagai sebuah lembaga pemerintah yang besar dan berhubungan dengan banyak komponen di Indonesia, Kemendagri sering mendapatkan masalah dalam hubungan nya dengan publik yang 
Edutech, Tahun 13, Vol.1, No.1, Februari 2014

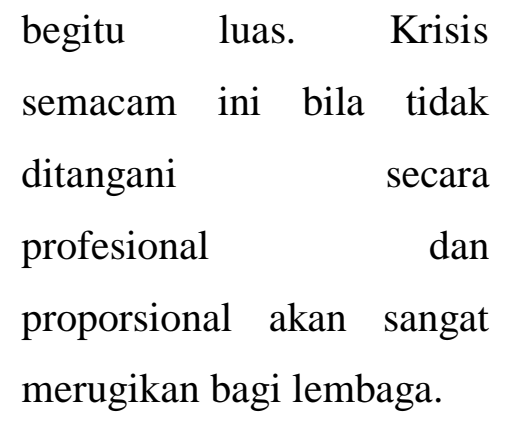

Saat menghadapi krisis

dengan publik, para pelaku

kehumasan Kemendagri

melakukan komunikasi

intensif dengan pihak

terkait dengan isu yang

menjadi tema krisis.

Selanjutnya berkonsultasi

atau melibatkan unit lain

untuk meningkatkan

pemahaman pelaku

kehumasan terhadap isu

tersebut. Termasuk juga

melibatkan Biro Hukum

Kemendagri untuk

mendapatkan advokasi atau

nasehat hukum untuk

memahami telaah dari sisi

peraturan tentang krisis

tersebut.

Pelaku kehumasan

Kemendagri selalu

mencoba untuk mengelola krisis dengan baik, dengan

tujuan agar krisis itu berbalik menjadi isu yang berbobot. Bahkan bisa saja, krisis bisa berbalik lebih menguntungkan bagai lembaga. Pelaku kehumasan Kemendagri memandang krisis adalah hal yang wajar terjadi dalam dinamika hubungan antara lembaga dan publiknya. Kunci menghadapi krisis adalah dengan membangun komunikasi antara semua unit yang terkait dengan tema krisis. Selanjutnya perlu dikembangkan pemikiran yang positif dan niat baik dalam diri pelaku humas Kemendagri untuk menyelesaikan krisis tersebut. Suka atau tidak suka, tatkala seseornag memilih profesi menjadi seorang pelaku kehumasan, ibarat seorang pelaut, dia pantang untuk pulang ke 
rumahnya hanya karena

badai. Krisis dalam dunia

kehumasan adalah bumbu profesi, tanpanya pekerjaan akan hambar.

\section{m. Model Implementasi Permendagri 13/2011 oleh Pejabat Humas Kemendagri}

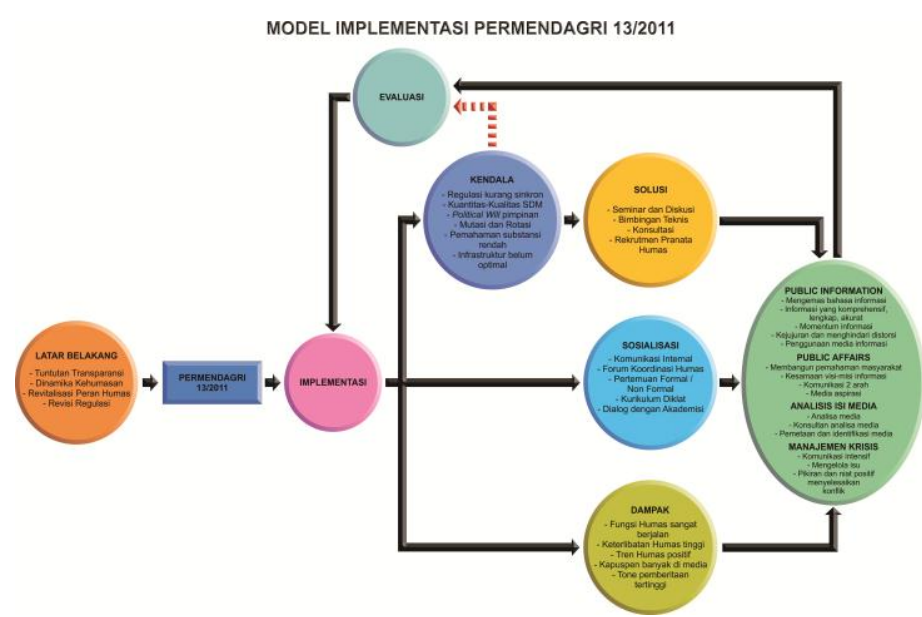

Model 2.2

\section{Model Implementasi Permendagri 13/2011}

\section{SIMPULAN}

Hasil penelitian menunjukkan bahwa pejabat humas Kemendagri memahami Permendagri 13/2011 sebagai regulasi yang mendorong Humas Kemendagri untuk meningkatkan profesionalismenya dan merupakan upaya untuk mendorong partisipasi aktif publik. Sementara dalam implementasi Permendagri 13/2011 ditemukan beberapa latar belakang lahirnya Permendagri kasih kepada : Prof.Dr.Hj.Mien

13/2011, terdapat upaya sosialisasi Permendagri 13/2011, dampak, kendala serta solusi terkait implementasi Permendagri 13/2011 dan 4 aktivitas kehumasan utama Kemendagri yaitu layanan public information, public affairs, analisis isi media dan manajemen krisis.

\section{Ucapan Terima Kasih}

Penulis menyampaikan terima 103 Optimalisasi Fungsi Humas Pemerintah The Optimization Of Government Public Relations Function 
Edutech, Tahun 13, Vol.1, No.1, Februari 2014

Hidayat,Dra.,M.S. sebagai ketua of Reality. Middlesex : Penguin komisi pembimbing dan Dr. $\mathrm{Hj}$. Books Nuryah Asri Sjafirah, M.Si. sebagai Bertens, K. 1999. Sejarah Filsafat anggota komisi pembimbing. Drs. Yunani,Yogyakarta: Kanisius.

Reydonnyzar Moenek, M.Devt. M, Black, Sam dan Sharpe. L Melvin. Kepala Pusat Penerangan Kemendagri. 1988. Ilmu Hubungan Seluruh jajaran Humas Kemendagri, diantaranya Andi Kriarmoni, S.E., Masyarakat Praktis. Jakarta : PT Intermasa.

S.IP., M.M.; Simon Saimima, S.TP., Bungin Burhan, 2003. Analisis Data M.Si.; Andri Indrawan, S.Sos., M.Si.; Penelitian Kualitatif

Drs. Indra Simaremare, M.Si. dan Yanuar Andriayana Putra, S.T..

\section{DAFTAR PUSTAKA}

Alwasilah, Chaedar A. 2002. Pokoknya

Kualitatif, Jakarta : PT Pustaka Jaya. Ardianto, Elvinaro dan Bambang QAnees. 2007. Filsafat Ilmu Komunikasi. Bandung: Simbiosa Rekatama Media.

Basrowi, Sukidin. 2002. Metode Penelitian Kualitatif Perspektif Mikro, Surabaya : Insan Cendekian

Berger, Peter L dan Thomas Luckman. 1990. Tafsir Sosial atas Kenyataan, Jakarta : LP3S

Berger, Peter L dan Thomas Luckman. 1991. The Social Construction Pemahaman Filosofis dan Metodologis Kearah Penguasaan Model Aplikasi. Jakarta : Raja Grafindo Persada.

BP2Ki. 2009. Menyoroti Komunikasi Politik Parpol. Bandung : Simbiosis

Rekatama Media.

Creswell, John. 1994. Research Design Qualitative And Quantitative Approaches. London : Sage Publications.

Cutlip, Scoot M., Allen H. Center, and Glen M. Broom. 2000. Effective Public Relations, New Jersey : Eight Editions, Prentice Hall Inc.

Freitag, Alan R. dan Ashli Quesinberry Stokes. Global Public Relations 104 Optimalisasi Fungsi Humas Pemerintah The Optimization Of Government Public Relations 
Edutech, Tahun 13, Vol.1, No.1, Februari 2014

: Spanning Borders,Spanning

Cultures. New York :

Routledge

Hidayat, Deddy Nur. 1999. Paradigma dan Perkembangan Penelitian Komunikasi dalam Jurnal Ikatan Sarjana Komunikasi Indonesia,VolIII. Jakarta: IKSI dan ROSDA

Jefkins, Frank. 1992. Public Relations. Jakarta : Arlangga.

Kasali, Rhenald. 2005. Manajemen Public Relations. Jakarta : PT Pustaka Utama Grafiti.

Kuswarno, $\quad$ Engkus. 2008. Fenomenologi. Bandung : Widya Padjadjaran.

Littlejohn, Stephen W., 1996. Theories of Human Communication. 5th Edition, Wadsworth, Belmont California.

Mickey, Thomas J. 2003. Deconstructing Public Relations: Public Relations Criticism. New Jersey : Lawrence Erlbaum Associates, Inc., Publishers

Moore, Frazier. 2004. Hubungan

Masyarakat, Prisip, Kasus dan
Masalah, Bandung : PT Remaja Rosdakarya.

Moleong, Lexy J.2002. Metodologi Penelitian Kualitatif, Jakarta : PT Remaja Rosdakarya.

Mulyana, Deddy. 2006. Metodologi Penelitian Kualitatif. Bandung : PT Remaja Rosdakarya. , Deddy dan Solatun. 2007. Metode Penelitian Komunikasi. Bandung : PT Remaja Rosdakarya.

Deddy. 2008. Ilmu Komunikasi: Suatu Pengantar. Bandung: PT. Remaja Rosdakarya.

Nugroho, Heru. 1999. Konstruksi Sara, Kemajemukan dan Demokrasi, UNISIA, No.40/XXII

Nyak Baik, Ridwan dan T Sati. 2004. Koalisi Dominan Refleksi kritis Atas Peran Dan Fungsi Public Relations Dalam Manajemen. Jakarta : BPP Perhumas.

Ritzer, George. 2004. Sociological Theory. New York : The McGraw-Hill Companies, Inc. 
Edutech, Tahun 13, Vol.1, No.1, Februari 2014

, George, 2004. Teori Sosiologi.

Cetakan Kelima. Kreasi

Wacana Offset, Bantul.

Rumanti, A. Maria. 2002. Dasar-Dasar

Public Relations Teori dan

Praktek. Jakarta : PT Gramedia

Widiasarana.

Ruslan, Rosady. 2003. Manajemen

Public Relations Dan Media

Komunikasi. Jakarta : PT Raja

Grafindo Persada.

Salim, Agus.2001. Teori dan

Paradigma Penelitian Sosial.

Yogyakarta : Tiara Wacana.

Suparno. $1997 . \quad$ Filsafat

Konstruktivisme dalam

Pendidikan,

Yogyakarta:Kanisius,

Sutopo. 2002. Metodologi Penelitian

Kualitatif. Surakarta : Sebelas

Maret University Press.

Sukidin, Basrowi. 2002. Metode

Penelitian Kualitatif Perspektif

Mikro.Surabaya : Insan

Cendekia.

Tench, Ralph dan Liz Yeomans. 2006.

Exploring Public Relations.

Essex : Pearson Education

Limited.
Theaker, Alison. 2001. The public

relations handbook, 2nd edition.

2 Park Square, Milton Park,

Abingdon, Oxfordshire :

Routledge

West, Richard dan Lynn H. Turner.

2008. Pengantar Teori

Komunikasi: Analisis dan

Aplikasi. Buku 1 edisi ke-3.

Terjemahan. Maria Natalia

Damayanti Maer. Jakarta:

Salemba Humanika.

Yin, Robert K. 2003. Case Study Research Design and Method. California : Sage Publication Inc. 